\title{
WWTP Effluent Quality Improvement for Agricultural Reuse Using an Autonomous Prototype
}

\author{
Laura Ponce-Robles ${ }^{1, * \mathbb{D}}$, Beatriz Masdemont-Hernández ${ }^{2}$, Teresa Munuera-Pérez ${ }^{2}$, \\ Aránzazu Pagán-Muñoz ${ }^{3}$, Andrés Jesús Lara-Guillén ${ }^{3}$, Antonio José García-García ${ }^{1}$, \\ Francisco Pedrero-Salcedo ${ }^{1}$, Pedro Antonio Nortes-Tortosa ${ }^{1}$ and Juan José Alarcón-Cabañero ${ }^{1}$ \\ 1 Department of Irrigation, Centro de Edafología y Biología Aplicada del Segura, CEBAS-CSIC, \\ 30100 Murcia, Spain; antonio.j.garcia2@gmail.com (A.J.G.-G.); fpedrero@cebas.csic.es (F.P.-S.); \\ panortes@cebas.csic.es (P.A.N.-T.); jalarcon@cebas.csic.es (J.J.A.-C.) \\ 2 SISTEMA AZUD, S.A., 30820 Murcia, Spain; beatriz@azud.com (B.M.-H.); tmunuera@azud.com (T.M.-P.) \\ 3 Technology Centre for Energy and the Environment (CETENMA), 30353 Murcia, Spain; \\ aranzazu.pagan@cetenma.es (A.P.-M.); alara@cetenma.es (A.J.L.-G.) \\ * Correspondence: lponce@cebas.csic.es; Tel.: +34-968-396-200
}

Received: 5 July 2020; Accepted: 5 August 2020; Published: 9 August 2020

\begin{abstract}
Wastewater reuse presents a promising way to mitigate the risk to global water resources and achieve sustainability in water, especially in agricultural areas in the southeast of Spain, such as the Murcia region. However, the risks related to the presence of contaminants of emerging concern (CECs) or pathogenic microorganisms in wastewater treatment plant (WWTP) effluent suggest the need to implement effective and relatively low-cost tertiary treatments. With this aim, a self-sustainable pilot prototype based on three combined modules (disc-filtration, granular activated carbon (GAC) bed adsorption and UV disinfection) assisted by solar panels was installed as an alternative tertiary treatment in a conventional WWTP in the Murcia region. The obtained results clearly confirmed the efficiency of the proposed prototype for CECs removal, and showed optimal results at a workflow of $500 \mathrm{~L} / \mathrm{h}$. In all cases, high removal efficiency was obtained for the different indicator microorganisms described in the recently published Regulation (EU) 2020/741 (E. coli, F-specific coliphages, somatic coliphages, total coliphages, and Clostridium perfringens). The protection of the activated carbon by disc-filters and the energy autonomy and self-operation of the prototype resulted in an efficient and economically viable methodology for its implementation in both conventional WWTPs and in isolated areas attached to crops.
\end{abstract}

Keywords: granular activated carbon; adsorption; autonomous prototype; emerging contaminants; filtration; reclaimed water; safe agricultural reuse

\section{Introduction}

Nowadays, the use of reclaimed water is seen as an excellent approach to deal with water scarcity. Indeed, water reuse is an important feature of water policies in most countries around the world, for example, it is included in WHO guidelines [1], and it is seen as a fundamental aspect of the concept of a circular economy [2]. In the European Union, one billion cubic meters of urban wastewater are reused annually (approximately $2.4 \%$ of treated effluents). However, this value is expected to increase by up to six times due to the development of numerous initiatives regarding water reuse for irrigation, industrial uses or aquifer recharge [3]. This practice not only promotes the efficient use of water, but also leads to prosperity from an environmental, human and economic point of view, and promotes management strategies for the safe discharge of wastewater into the environment and protection of surface and groundwater [4]. Possible reuse applications include agricultural or 
landscape irrigation, groundwater recharge, industrial activities, street cleaning or ecological uses [5,6]. In particular, in semi-arid areas of the Mediterranean basin, where agriculture is the highest consumer of water (approximately 68\% in Spain, 50\% in Italy and 80\% in Greece), the use of reclaimed water for agricultural purposes is essential [7-9]. Water reuse also has important economic and environmental benefits, such as the possibility of nutrient recovery or reduction in fertilizer use [10,11]. However, the use of reclaimed water in agriculture requires quality control to guarantee satisfactory sanitary conditions. Therefore, one of the current goals is the development and improvement of technologies that enable the adequate treatment of wastewater [12] and to achieve the discharge limits established for agricultural uses according to the current and future legislation. Specifically, at the European level, the recently published Regulation (EU) 2020/741 of the European Parliament and of the Council of 25 May 2020 (https://eur-lex.europa.eu/legal-content/EN/TXT/?uri=uriserv\%3AOJ.L_.2020.177.01. 0032.01.ENG\&toc=OJ\%3AL\%3A2020\%3A177\%3ATOC) on minimum requirements for water reuse establishes the minimum quality requirements to use reclaimed water for agricultural purposes, to ensure a high level of protection of the environment and human and animal health, and to promote the circular economy [13]. The Commission estimates that new regulations could increase water reuse in agricultural irrigation from 1.7 billion $\mathrm{m}^{3}$ to 6.6 billion $\mathrm{m}^{3}$ per year, thereby reducing water stress by 5\% (EU, 2018 estimations) [14]. However, special attention has recently been given to so-called "contaminants of emerging concern" (CECs), which are mostly unregulated compounds that may be candidates for future regulation, depending on research on their potential effects on health and data that monitors their occurrence. The list of CECs includes a wide variety of products for daily use in both industrial and domestic applications, such as pharmaceuticals and personal care products (PPCPs), hormones, surfactants, endocrine disruptors, antiseptics, pesticides and synthetic fragrances [15,16].

One of the main sources of water for potential agricultural reuse comes from municipal wastewater treatment plants (WWTPs). However, conventional secondary (usually activated sludge processes) and tertiary (media filtration and disinfection) wastewater treatments are not effective in the removal of CECs [17-19]. Several authors have studied the removal efficiencies of different CECs in conventional WWTP using activated sludge. Behera et al. reported low removal values for carbamazepine (23.1\%), atenolol (64.5\%), metoprolol (23\%), sulfamethazine (13.1\%) and sulfamethoxazole (51.9\%) [20], while Radjenovic et al. reported low removal values for compounds such as diclofenac (50.1\%), indomethacin (23.4\%), mefenamic acid (29.4\%), ofloxacin (23.8\%) and erythromycin $(23.8 \%)$ [21]. The presence of CECs in WWTPs effluent due to low removal efficiencies is of particular relevance in agricultural reuse because of the possibility of CECs uptake and accumulation in food crops and consequent diffusion into the food chain. Although some CECs are already among the priority research lines of the main organizations dedicated to the protection of public and environmental health, such as WHO and environmental protection agencies such as the Environmental Protection Agency (EPA), no legal discharge limits are described in the current legislation. However, due to the growing interest in these substances, some of them, such as diclofenac and erythromycin are included in the European Union Watch List (Directive, 2013/39/EU, modified by Decision 2015/495/EU of 20 March 2015 and updated in Decision 2018/840/EU of 5 June 2018) and discharge limits will probably be included in future regulations [22-24].

With that in mind, the implementation of tertiary treatments in real WWTPs specifically designed for CECs removal will be crucial to efficiently obtain safe, high-quality reclaimed water. This will increase the trust of farmers and the final consumers of the products and simplify the proper management of the water. However, the problems that these compounds may generate in the short or long term, the lack of specific legislation obliging WWTPs to use such treatments, along with other economic problems (investment costs, maintenance, energy consumption, the need for high-complexity analytics) make it difficult to implement the appropriate treatments in WWTPs. Other factors that may limit the implementation of specific technologies in WWTPs include the great diversity of existing CECs, and the different physico-chemical properties that they have. 
Recent studies have focused on several treatment processes applied for the removal of CECs such as advanced biological processes (membrane bioreactors and bio-electrochemical systems) $[25,26]$, and advanced oxidation processes (AOPs) $[27,28]$. The main limitations of these types of technologies are their high operating costs, specific infrastructures and high energy consumption. Other alternatives such as activated carbon adsorption and ozonation are considered as economically feasible options that can be coupled to WWPTs [29], however, the use of ozone may be associated with the generation of by-products, which can be hazardous to health if the water is used for agricultural purposes.

In this context, the adsorption of CECs by granular activated carbon (GAC) is a promising technology due to its removal efficiency at relatively low cost [30]. In general, and due to its properties (such as its high porosity, high surface area and high degree of surface interactions), activated carbon has a high adsorption capacity for a wide spectrum of CECs [31,32]. In addition, this process has the advantage of not generating secondary by-products [32,33]. Although the effectiveness of adsorption processes in CECs removal is well-known, the introduction of tertiary treatments in conventional WWTPs for the purpose of safe water for agricultural reuse is poorly implemented. This is mainly due to a lack of knowledge about adsorption mechanisms, the great diversity of CECs present in wastewater, the large amount of wastewater interference, and lack of knowledge about the design of systems capable of removing CECs that guarantee the production of CEC-free effluent at relatively low costs.

The aim of this work was the integration of a self-sustainable pilot plant prototype in a conventional WWTP for the purpose of safe agricultural reuse. The design focused on the removal of CECs and microbiological risks by using a combined Filtration-GAC-UV system, in line with current and future legislation. The use of water from a real WWTP together with data on the efficiency and associated economic costs will give us a practical view of the implementation of such systems.

\section{Materials and Methods}

\subsection{Wastewater Samples}

The water source used in the experiments for this study was a WWTP located in the Murcia region (Spain), (latitude $37^{\circ} 47^{\prime} 48^{\prime \prime} \mathrm{N}$, longitude $0^{\circ} 57^{\prime} 36^{\prime \prime} \mathrm{W}$ ). This plant receives domestic and industrial effluent from three municipalities (Roldán, Lo Ferro and Balsicas) and has a maximum treatment capacity of 2,007,500 $\mathrm{m}^{3} /$ year of wastewater.

This WWTP consists of a secondary treatment based on active sludge with extended aeration and secondary sedimentation. It also uses a tertiary treatment based on coagulation-flocculation, rapid sand filter and disinfection using ultraviolet (UV) radiation. Treated wastewater is commonly used for agricultural irrigation in the Campo de Cartagena area.

\subsection{Chemicals and Reagents}

Seven CECs that have been detected worldwide in WWTP influents and effluents (Tran et al., 2018) were selected for the study: (acetaminophen (ACT), carbamazepine (CBZ), diclofenac (DCF), erythromycin (ERY), ketoprofen (KTP), naproxen (NPX) and sulfamethoxazole (SMX)) [16]. Sigma-Aldrich (Steinheim, Germany) analytical standards of these compounds at high purity grade $(>99 \%)$ were used. The physico-chemical properties and chemical structure of these CECs are given in Table 1. 
Table 1. Physico-chemical properties and chemical structure of selected contaminants of emerging concern (CECs).

\begin{tabular}{|c|c|c|c|c|c|}
\hline Compound & Structure & $\mathrm{Mw}(\mathrm{g} / \mathrm{mol})$ & $\begin{array}{l}\text { Water Solubility } \\
\quad(\mathrm{mg} / \mathrm{L})\end{array}$ & Log Kow & pKa \\
\hline $\begin{array}{l}\text { Acetaminophen } \\
\text { (ACT) } \\
\text { NSAIDs }{ }^{1}\end{array}$ & & 151.17 & $14,000\left(\right.$ at $\left.25^{\circ} \mathrm{C}\right)$ & 0.46 & 9.38 \\
\hline $\begin{array}{l}\text { Carbamazepine } \\
\text { (CBZ) } \\
\text { Anticonvulsant }\end{array}$ & & 236.27 & $18\left(\right.$ at $\left.25^{\circ} \mathrm{C}\right)$ & 2.45 & 13.9 \\
\hline $\begin{array}{l}\text { Diclofenac } \\
\text { (DCF) } \\
\text { NSAIDs } 1\end{array}$ & & 296.15 & $2.37\left(\right.$ at $\left.25^{\circ} \mathrm{C}\right)$ & 4.51 & 4.15 \\
\hline $\begin{array}{l}\text { Erytromycin } \\
\text { (ERY) } \\
\text { Antibiotic }\end{array}$ & & 733.94 & $4.2\left(\right.$ at $25^{\circ} \mathrm{C}$ ) & 3.06 & 8.88 \\
\hline $\begin{array}{l}\text { Ketoprofen } \\
\text { (KTP) } \\
\text { NSAIDs }{ }^{1}\end{array}$ & & 254.29 & $51\left(\right.$ at $\left.22{ }^{\circ} \mathrm{C}\right)$ & 3.12 & 4.45 \\
\hline $\begin{array}{l}\text { Naproxen } \\
\text { (NPX) } \\
\text { NSAIDs }{ }^{1}\end{array}$ & & 230.26 & 15.9 (at $25^{\circ} \mathrm{C}$ ) & 3.18 & 4.15 \\
\hline $\begin{array}{l}\text { Sulfamethoxazole } \\
\text { (SMX) } \\
\text { Antibiotic }\end{array}$ & & 253.27 & $610\left(\right.$ at $\left.37^{\circ} \mathrm{C}\right)$ & 0.89 & $1.6 / 5.7$ \\
\hline
\end{tabular}

${ }^{1}$ NSAIDs: Nonsteroidal anti-inflammatory drugs. 
A commercial coconut shell-based GAC with high density value $\left(520 \pm 30 \mathrm{~kg} / \mathrm{m}^{3}\right)$ was used as adsorbent in accordance with Benstoem et al. [34]. In that paper, the authors described a high correlation between the high density of GAC sorbents and their capacity to adsorb CECs.

The selected GAC was activated thermally with steam and supplied by Chiemivall (Castellbisbal, Barcelona, Spain). The main properties are described in Table S1, Supplementary Materials.

\subsection{Analytical Determinations}

Wastewater samples were characterized in terms of $\mathrm{pH}$, turbidity, electrical conductivity (EC), dissolved organic carbon (DOC), total suspended solids (TSS), five-day biochemical oxygen demand (BOD5), and some ions (for conditions, see Appendix A).

The microbiological analysis of the CECs (ACT, CBZ, DCF, ERY, KTP, NPX and SMX) (Clostridium perfringens spores, Escherichia Coli and total coliphages (somatic and F-specific)) was done by an external ISO 17025 certified laboratory (IPROMA S.L.) located in Castellón, Spain. For CECs, SPE extraction followed by HPLC-MS (High-performance liquid chromatography - mass spectrometry) was used. Clostridium perfringens spores and Escherichia Coli were determined by plate count while coliphages (total, somatic and F-specific) were determined using the double agar layer method (ENAC $n^{\circ}$ 109/le285 accreditation, https://www.enac.es/documents/7020/ac514131-7717-42cc-b026-0b8de53c78e1.

\subsection{Preliminary Lab-Scale Experiments}

The adsorption capacity of the selected GAC was studied at lab scale using a methacrylate column of $550 \mathrm{~mm}$ length and $19 \mathrm{~mm}$ internal diameter containing $21.5 \mathrm{~g}$ of GAC. The experiments were carried out using secondary WWTP effluents fortified with $200 \mu \mathrm{g} / \mathrm{L}$ of each CEC. The mixture was added to a plastic tank and pumped into the column by a peristaltic pump (P-Selecta, Percom-I model, (J.P. Selecta, Abrera, Barcelona, Spain) Operational parameters (Table 2) were selected according to previous results described in the literature [35], which were also compatible with the dimensions established for the design of the experimental prototype.

Table 2. Operational parameters of the adsorption lab-scale preliminary experiments.

\begin{tabular}{lc}
\hline Parameter & Units \\
\hline GAC bed height & $20 \mathrm{~cm}$ \\
Empty bed contact time & $39.38 \mathrm{~s}$ \\
Filtration area of GAC & $2.8 \mathrm{~cm}^{2}$ \\
Flow rate & $5.18 \mathrm{~L} / \mathrm{h}$ \\
Filtration velocity & $18.28 \mathrm{~m} / \mathrm{h}$ \\
Volume of water & $145 \mathrm{~L}$ \\
needed & \\
\hline
\end{tabular}

Effluent was collected from the lab-system at different time intervals until the concentration remained constant over time. The amount of adsorbed CEC was calculated as follows [36,37]:

$$
q_{e}=\frac{\left(\mathrm{C}_{0}-\mathrm{C}_{i}\right) \times V}{m}
$$

where $\mathrm{C}_{0}$ is the initial CEC concentration $(\mu \mathrm{g} / \mathrm{L}), C_{i}$ is the CEC concentration in treated wastewater $(\mu \mathrm{g} / \mathrm{L}), V$ is the volume of treated wastewater $(\mathrm{L})$ and $m$ is the mass of GAC $(\mathrm{g})$. All adsorption experiments were performed at least twice and the results are reported as an average.

\subsection{Plant Prototype Design}

The prototype (Figure 1) was designed, manufactured and installed by AZUD in the CEBAS-CSIC's Research Platform inside the Roldán-Lo Ferro-Balsicas WWTP, and it was directly connected to effluent from the secondary treatment. 

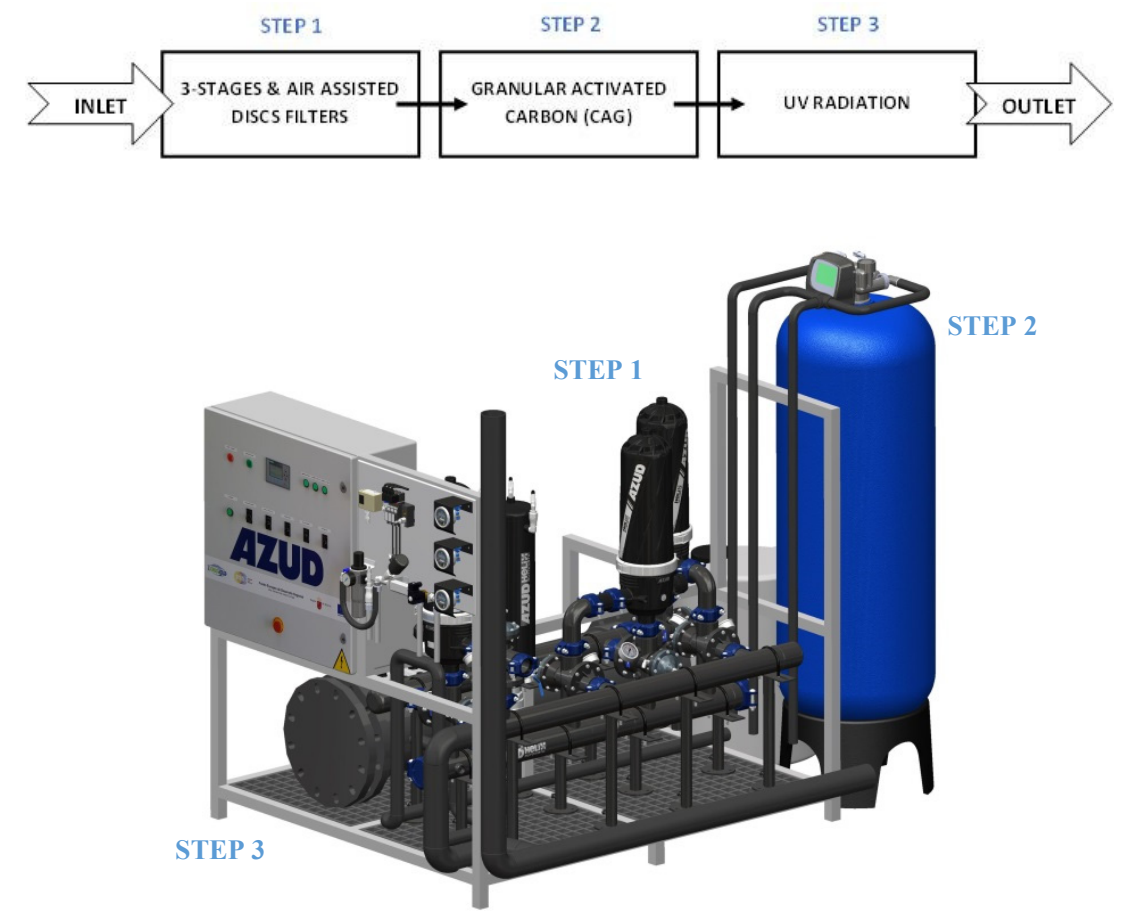

Figure 1. Prototype design.

The maximum workflow of the prototype is $1200 \mathrm{~L} / \mathrm{h}$ although hydraulically it is capable of working with lower flows (minimum $500 \mathrm{~L} / \mathrm{h}$ ). The water treatment includes three steps:

1 The first step is based on disc filters AZUD HELIX AUTOMATIC ${ }^{\circledR}$.

The objective of the first step is to filter the water out of the secondary settling tanks in order to allow the next step of the treatment (GAC) to work specifically on the adsorption of the CECs without any interference due to suspended particles that might reduce the adsorption performance.

Disc filters were selected to achieve this because this allows for a deep filtration that eliminates all particles larger than the degree of filtration and a high percentage of smaller ones, regardless of the geometry or nature of the particles. This is also an effective way of protecting the rear media filter. The disc filter module has a specific design that combines three independent stages working in series with several selected particle retention capacities (50,20 and $5 \mu \mathrm{m}$ ). This experimental module includes an automatic backwash system that combines water and compressed air, which allow for the disc recovery. The air-assisted backwash system (AA) works with low pressure (even during the backwash process), thus reducing the hydraulic interaction in the prototype during cleaning and optimizing the water and energy consumption as well as obtaining total recovery of the discs. The backwashing times was $30 \mathrm{~s}$ for each stage.

2 The second step is based on the adsorption process using a high-quality coconut shell-based GAC.

A total of $112 \mathrm{~kg}$ of CG900 (Chiemivall, Castellbisbal, Barcelona, Spain), (see Table S1, Supplementary Materials) was placed in a bed column made of polyester reinforced with fiberglass of $1945 \mathrm{~mm}$ high with an auto-control valve. Weekly cleaning of the module was scheduled to ensure maximum repetitiveness of the analytical results.

3 The third step is based on a system for disinfection with UV radiation. This step was designed for disinfection purposes and consists of a conventional $\lambda=245 \mathrm{~nm}$ UV lamp with 200-400 W that was self-assembled in the prototype. 
The prototype is totally autonomous due to the automation of all processes. Five solar panels (270POL, Sunconnection WorldWide 2016 ${ }^{\circledR}$, Murcia, Spain) were installed outside to provide the required electric energy (Figure 2a). The panels supply a total of $1650 \mathrm{~W}$, while the prototype consumes energy in a range between $840 \mathrm{~W}$ and $1600 \mathrm{~W}$ depending on the selected configuration (For more details, see Table S2). Solar panels were connected to the electric feed of the system through a set of batteries (Figure $2 b$ ) for the continuous operation of the system even when the solar radiation is low or during the hours without sun.

(a)

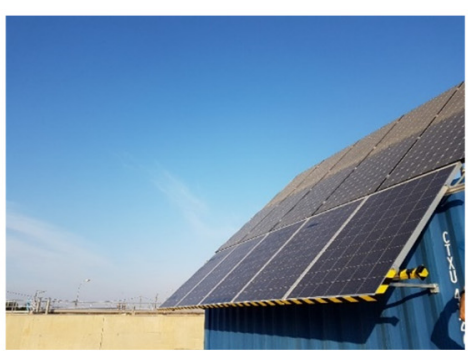

(b)

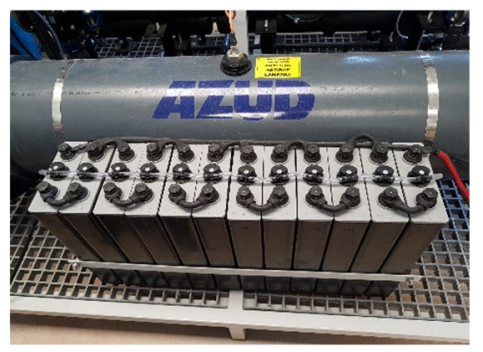

Figure 2. (a) Solar panels (the lined ones in the lower part of the picture); (b) Set of batteries.

\section{Results and Discussion}

\subsection{Characterization of WWTP Effluent}

Samples from the secondary effluent from the WWTP were characterized between March and June 2019 in order to assess the variability in real effluents. Table 3 shows the average, minimum and maximum values of the different physico-chemical parameters analyzed. In general, low standard deviations were obtained for almost all parameters analyzed, indicating effluent stability. The greatest variations in standard deviation were found in the analysis of $\mathrm{Cl}^{-}$and $\mathrm{SO}_{4}{ }^{2-}$, which coincided with samples taken from point of entry to the WWTP.

Table 3. Characteristics of secondary wastewater treatment plant effluents $(n=20)$.

\begin{tabular}{|c|c|c|c|c|}
\hline Parameters & Minimum & Maximum & Average & SD \\
\hline $\mathrm{pH}$ & 7.19 & 7.73 & 7.43 & 0.15 \\
\hline Turbidity (NTU) & 0.95 & 7.79 & 2.66 & 1.60 \\
\hline Electrical Conductivity (EC, dS/m) & 1.11 & 1.80 & 1.57 & 0.15 \\
\hline 5-day Biochemical Oxygen Demand $\left(\mathrm{BOD}_{5}, \mathrm{mg} / \mathrm{L}\right)$ & 3.00 & 12.00 & 6.25 & 4.03 \\
\hline Total Nitrogen $(\mathrm{mg} / \mathrm{L})$ & 6.55 & 11.74 & 9.42 & 1.82 \\
\hline Dissolved organic carbon (mg/L) & 9.76 & 13.90 & 11.67 & 1.39 \\
\hline Total Solids (TSS, mg/L) & 3.00 & 10.00 & 5.50 & 2.00 \\
\hline Transmittance (\%) & 48.80 & 64.70 & 53.69 & 4.58 \\
\hline $\mathrm{F}^{-}(\mathrm{mg} / \mathrm{L})$ & $<0.02$ & 0.14 & 0.18 & 0.03 \\
\hline $\mathrm{Cl}^{-}(\mathrm{mg} / \mathrm{L})$ & 141.72 & 301.02 & 243.57 & 47.13 \\
\hline $\mathrm{NO}_{2}^{-}(\mathrm{mg} / \mathrm{L})$ & $<0.10$ & 1.44 & 1.38 & 0.08 \\
\hline $\mathrm{Br}^{-}(\mathrm{mg} / \mathrm{L})$ & 0.26 & 0.51 & 0.38 & 0.08 \\
\hline $\mathrm{NO}_{3}^{-}(\mathrm{mg} / \mathrm{L})$ & 2.45 & 19.74 & 9.93 & 5.74 \\
\hline $\mathrm{PO}_{4}{ }^{3-}(\mathrm{mg} / \mathrm{L})$ & 5.96 & 14.67 & 9.08 & 2.91 \\
\hline $\mathrm{SO}_{4}{ }^{2-}(\mathrm{mg} / \mathrm{L})$ & 136.00 & 231.03 & 200.82 & 30.91 \\
\hline SAR & 2.83 & 5.59 & 4.90 & 1.01 \\
\hline
\end{tabular}

\subsection{Adsorption Capacity of Selected GAC}

Before the commissioning of the prototype, the GAC maximum adsorption capacity was determined at lab-scale. The results (reported as the average concentration of all selected CECs) showed that after $120 \mathrm{~L}$ of wastewater was treated, the concentration remains constant, so, with regard to Equation (1), the maximum adsorption capacity was determined as $0.8 \mathrm{mg}$ CECs/g GAC. 
Therefore, a maximum adsorption of $89.6 \mathrm{~g}$ of CECs can be expected in the GAC bed column of the self-sustainable prototype.

\subsection{Prototype Evaluation and Optimization}

\subsubsection{Disc-Filter Module}

To evaluate the operation and efficiency of the disc-filter module, the pressure differential was continuously monitored, since this parameter allows evaluation of the degree of filter fouling. A conservative maximum pressure value for each of the selected filters (50,20 and $5 \mu \mathrm{m})$ was set at 0.6 bars. When this value was reached, the automatic backwashing process was activated. The results (Figure 3) showed that of the total volume of prototype influent, only $0.23 \%$ was used for cleaning the filters, while $8.9 \%$ was destined to a second module cleaning (GAC bed column), and the water obtained was $90.87 \%$ of the total volume.

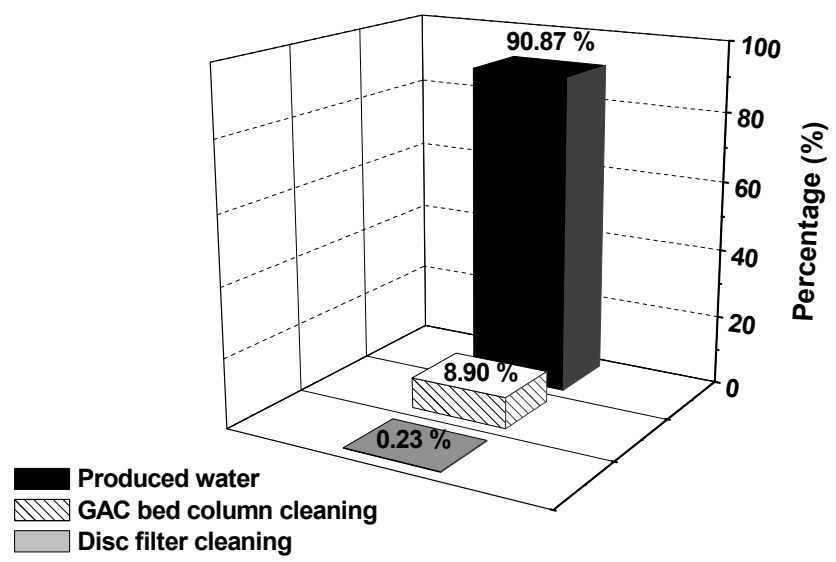

Figure 3. Percentages of produced water, granular activated carbon (GAC) bed column cleaning and disc filter cleaning from total treated volume.

Our results are in accord with Ravina et al. [38], who suggested that by using disc filters, the volume of the backwash water was generally less than $0.5 \%$ of the total volume passing though the filter. However, considering that this low percentage corresponds to the cleaning of the filter with the smallest particle size $(5 \mu \mathrm{m})$, the number of backwashes with respect to the accumulated treated volume was studied in order to evaluate the long-term efficiencies of the module (Figure 4). A total volume of $1000 \mathrm{~m}^{3}$ of real secondary WWTP effluents was passed through the filtering module. The variability in the frequency of cleaning is mainly due to the TSS that can enter the filters from secondary WWTP effluents according to Duran-Ros et al. [39], however, in almost all cases, values under 20 were obtained. The trend followed a virtually horizontal line, indicating that the incidence of cleaning remained constant over time, which suggests that the system is able to recover its initial state. In general, system fouling is related to the cleaning frequency, so that if the cleaning frequency increases, the filtering capacity decreases, until the filter clogs. For a detailed investigation of disc filter fouling, it would be necessary to do a study with much larger volumes or to work with effluents containing higher TSS values (as shown in Table 3, the selected effluents have low TSS values). 


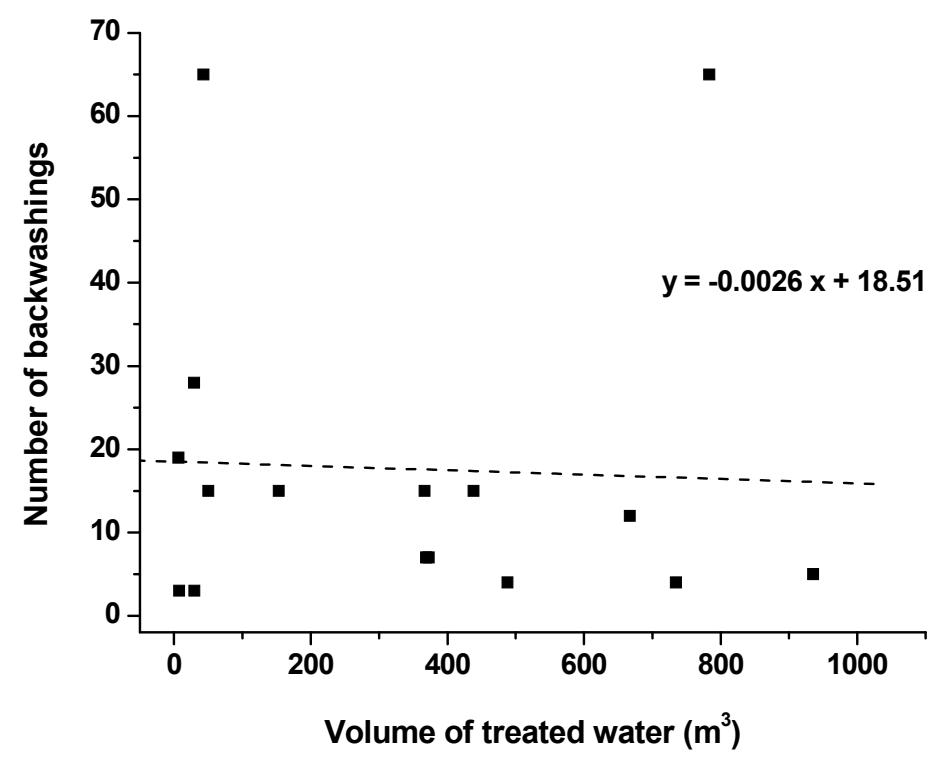

Figure 4. Number of automatic backwashes performed with respect to the treated volume.

\subsubsection{GAC Bed Column Module}

- Flow rate effects on CECs removal efficiency

In general, the retention time of CECs in the bed column is one of the most important factors affecting the efficiency of adsorption, due to its influence on both the adsorbate and adsorbent. The variation in empty bed contact time (EBCT) in the GAC bed column was studied through the variation in the workflow rate. The maximum and minimum prototype workflow (1200 and $500 \mathrm{~L} / \mathrm{h})$, and three intermediate points $(1000,800$, and $600 \mathrm{~L} / \mathrm{h})$ were studied. The values of the EBCT that corresponded with these points are detailed in Table 4 . All experiments were performed by introducing real secondary WWTP effluents into a $5000 \mathrm{~L}$ mixing tank where additional quantities of each CECs $(200 \mu \mathrm{g} / \mathrm{L})$ were added. In order to obtain representative results, experiments were performed during several months (September and November 2019 and February 2020) and all analytical samples were analyzed in duplicate. The overall results are shown in Table 4.

Table 4. CECs, dissolved organic carbon (DOC), turbidity and transmittance values obtained at different workflows $(n=6)$.

\begin{tabular}{ccccccc}
\hline $\begin{array}{c}\text { Workflow } \\
\mathbf{( L / h )}\end{array}$ & EBCT (min) & HLR * (m/h) $^{\text {Thetal CECs }}$ & $\begin{array}{c}\text { DOC } \\
\text { Removal (\%) }\end{array}$ & $\begin{array}{c}\text { Turbidity } \\
\text { Removal (\%) }\end{array}$ & $\begin{array}{c}\text { Transmittance } \\
\text { Removal (\%) }\end{array}$ \\
\hline Increase (\%)
\end{tabular}

In all experiments, $\mathrm{pH}$ values remained constant at neutral $\mathrm{pH}$ (7.1-7.9). The selected CECs were moderately to effectively removed over the entire course of the experiments, with mean ( \pm standard deviation) removals ranging from $52.5 \% \pm 2.2 \%$ to $74.6 \% \pm 6.1 \%$. Results showed that CECs removal increased with the EBCT values, indicating that lower flow rates are most effective for CECs adsorption compared with higher flow rates. The same tendency occurred with DOC and turbidity removals, while an increase of $\%$ transmittance was detected. According to Rahman et al., this is due to two phenomena: (i) lower workflow rates imply higher residence time in the bed column, and (ii) compounds or ions present in wastewaters have more time to diffuse into the pores of GAC through intra-particle 
diffusion [40]. Therefore, in order to obtain high-quality effluents for agricultural uses, a workflow of $500 \mathrm{~L} / \mathrm{h}$ (EBCT $27 \mathrm{~min}$ ) showed the best adsorption efficiencies. Under these conditions, the ability to remove individual CECs was evaluated.

The results (Figure 5) showed that the adsorption capacity for individual CECs followed the following trend: ACT $>$ CBZ $>$ NPX $>$ KTP $>$ DCF $>$ ERY $>$ SMX. The best adsorption results $(95.77 \pm 4.3 \%)$ were obtained for ACT mainly due to its low molecular weight compared to the rest of the CECs and its aromatic structure (see Table 1). In general, adsorption capacity is strongly related to the physical-chemical properties of CECs. Those with smaller molecular weights and aromatic compounds are more susceptible to adsorption in GAC systems, while higher molecular weight or low aromatic compounds are poorly adsorbed by GAC [41,42].

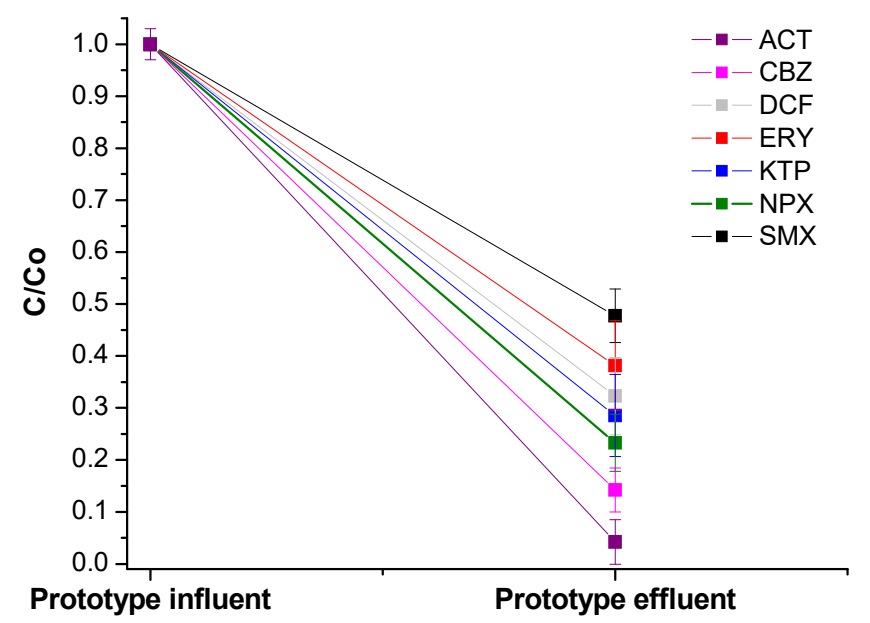

Figure 5. Adsorption efficiencies of selected CECs in workflow of $500 \mathrm{~L} / \mathrm{h}$.

Specifically, ERY has a significantly higher molecular weight than the rest $(733.94 \mathrm{~g} / \mathrm{mol})$. Furthermore, it is not aromatic, which has proven to be a disadvantageous adsorption characteristic, and it showed lower adsorption values in comparison with the other compounds $(61.81 \% \pm 8.61 \%)$.

The behavior of SMX is unusual compared to the above-it showed the lowest adsorption capacity $(52.24 \% \pm 5.15 \%)$. This may be related to its reactivity in aqueous solution, which results in two dissociation constants [43]. Because of this, SMX may be present in solutions in anionic form. Anionic species have a low tendency to adsorption by GAC, and may also be displaced by other adsorbates according to Yang et al. [44]. The low adsorption efficiency of SMX in GAC systems has been reported by several authors. For example, Motwani et al. reported that only $27.27 \%$ of SMX was removed using GAC with a particle size of $2.0-5.0 \mathrm{~mm}$, while none or little adsorption were described by Telgmann et al. using different GAC sorbents $(8 \times 30$ mesh, $4 \times 8$ mesh and $8 \times 14$ mesh of particle size $)[45,46]$.

- Inlet CECs concentration effects

Similar to previous studies, the effects of inlet CECs concentration were studied using real secondary WWTP effluents. Additional quantities of each CEC (at two different concentrations that differ by almost an order of magnitude, 200 and $50 \mu \mathrm{g} / \mathrm{L}$ ) were introduced in a $5000 \mathrm{~L}$ mixing tank, and spiked effluents were passed through the GAC bed column at a workflow of $500 \mathrm{~L} / \mathrm{h}$. All analytical samples were analyzed in triplicate and the results are reported in Figure 6. 


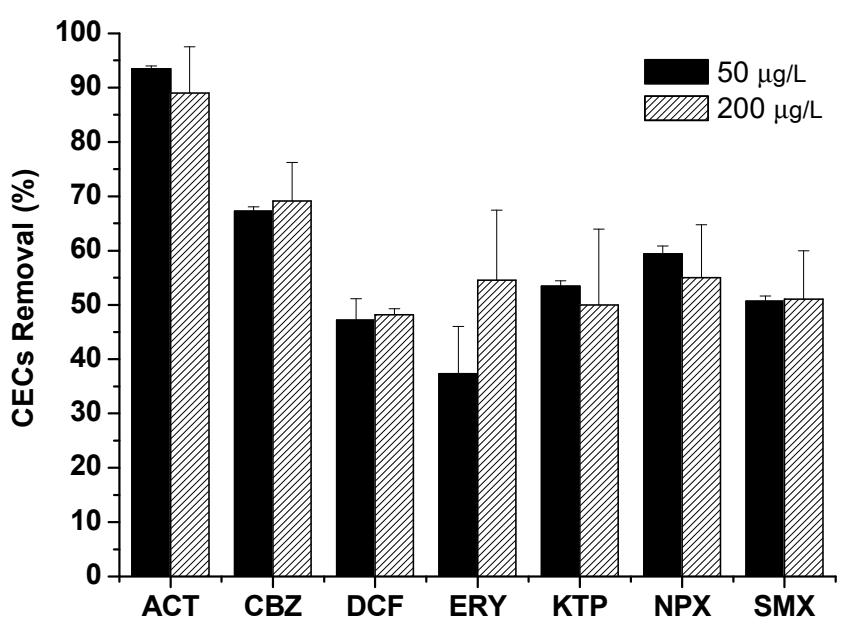

Figure 6. CECs removal percentages at two inlet concentrations (200 and $50 \mu \mathrm{g} / \mathrm{L}$ ).

With regard to the high variability of real WWTP secondary effluents, no significant effects were found between two studied CECs concentrations, except for ERY, which increased from $37.29 \pm 8.76 \%$ to $54.55 \pm 12.86 \%$ with concentrations of 50 and $200 \mu \mathrm{g} / \mathrm{L}$, respectively. This can be explained by considering that at high initial concentrations, the ratio of ERY molecules to adsorbent GAC active sites is high, therefore, the probability of the interaction of molecules increases. Similar effects of inlet concentration are common in GAC systems and these have been included in several studies. Sotelo et al. [47] reported an increase in the percentage of caffeine (from $77.71 \%$ to $91.74 \%$ ) and diclofenac (from $58.75 \%$ to $71.54 \%$ ) adsorption when the initial concentration of these compounds increased from 3 to $7 \mathrm{mg} / \mathrm{L}$, while Ang et al. [48] reported an increase in sevoflurane (an anesthetic) adsorption (from $536 \pm 5 \mathrm{mg} / \mathrm{g}$ to $604 \pm 9 \mathrm{mg} / \mathrm{g}$ and from $329 \pm 5$ to $368 \pm 5 \mathrm{mg} / \mathrm{g}$ ) when two different GACs (E-GAC and H-GAC, respectively) were used at inlet concentrations from 55.9 and $527.9 \mathrm{mg} / \mathrm{L}$.

\subsubsection{UV-Module Efficiency}

Removal of pathogenic microorganisms is essential to guarantee the high quality of prototype effluents. Therefore, the efficiency of the selected UV-lamp was evaluated by monitoring different indicator microorganisms as described in the recently published Regulation (EU) 2020/741 of the European Parliament and of the Council of 25 May 2020 on minimum requirements for water reuse (E. coli for pathogenic bacteria, F-specific coliphages, somatic coliphages and total coliphages for pathogenic viruses, and Clostridium perfringens spores for protozoa) [13]. The monitoring of these indicators in influent and effluent prototype samples was carried out for a period of one year (March 2019-March 2020) and the values are shown in Table 5. The maximum and minimum prototype workflow (1200 and $500 \mathrm{~L} / \mathrm{h}$ ) was also evaluated.

Table 5. Monitoring of microbiological indicators in the prototype at two workflows (500 and $1200 \mathrm{~L} / \mathrm{h}$ ) during a period of one year $(n=40)$.

\begin{tabular}{|c|c|c|c|c|c|}
\hline Indicator & \multicolumn{3}{|c|}{ Prototype Influent Values } & \multicolumn{2}{|c|}{$\%$ Removal } \\
\hline Clostridium perfringens spores (CFU/100 mL) & 310 & 16,000 & 3000 & 100 & 99.9 \\
\hline Total Coliphages (MPN/100 mL) & 2 & 220 & 47 & 100 & 100 \\
\hline Somatic Coliphages (MPN/100 mL) & $<1$ & 210 & 45 & 100 & 100 \\
\hline F-Specific Coliphages (MPN/100 mL) & $<1$ & 8 & 3 & 100 & 100 \\
\hline
\end{tabular}


Clostridium perfringens spores and Escherichia coli were detected in all prototype influent samples with average values of 3000 and $9484 \mathrm{CFU} / 100 \mathrm{~mL}$, respectively, while lower values were detected for Coliphages (the average values for total, somatic and F-Specific were 47, 45 and $3 \mathrm{MPN} / 100 \mathrm{~mL}$, respectively).

At a workflow of $500 \mathrm{~L} / \mathrm{h}$, all microbiological parameters were removed, while an average $0.1 \%$ decrease in Clostridium perfringens spores and Escherichia coli was detected for workflows of $1200 \mathrm{~L} / \mathrm{h}$. Despite this small loss of efficiency, high-quality effluents were obtained in all cases according to (EU) 2020/741 regulations [13], and they also complied with the most restrictive crop category values (Class A: All food crops consumed raw where the edible part is in direct contact with reclaimed water and root crops consumed raw).

Therefore, and independently of the workflow, high-quality effluents for reuse purposes were obtained, which minimized the microbiological risk of ingesting any type of crop irrigated with reclaimed waters.

\subsubsection{Continuous Operation of the Prototype}

Considering the previous results for CECs and microbiological indicators removal, the workflow was adjusted to $500 \mathrm{~L} / \mathrm{h}$ and the continuous operational work mode was evaluated. The work time was set for $8 \mathrm{~h}$ of work per day and weekly samples were evaluated for several months (March 2019-2020). At each sampling, both the influents (samples from the secondary treatment of the WWTP) and the prototype effluents were analyzed.

Analysis of the CECs in the prototype influent showed low concentration values for the selected compounds, with a minimum and maximum of $0.4 \mu \mathrm{g} / \mathrm{L}$ (DCF) and $3.20 \mu \mathrm{g} / \mathrm{L}(\mathrm{KTP})$, while ACT and ERY were not found in any analyzed sample with values below the analytical limits (limit of quantitation (LOQ)) marked by the reference laboratory that analyzed the samples (Table 6). The physico-chemical and microbiological analysis of prototype influents showed values within the ranges in all cases as previously described in Tables 1 and 5.

Table 6. CECs concentration in the prototype influent.

\begin{tabular}{cccc}
\hline \multirow{2}{*}{ CECs } & LOQ $(\mu \mathrm{g} / \mathrm{L})$ & \multicolumn{2}{c}{ Prototype Influent Concentration $(\mu \mathrm{g} / \mathrm{L})$} \\
\cline { 3 - 4 } & & Minimum & Maximum \\
\hline ACT & 0.4 & $<$ LOQ & $<\mathrm{LOQ}$ \\
CBZ & 0.2 & $<$ LOQ & 0.53 \\
DCF & 0.2 & 0.40 & 1.30 \\
ERY & 0.2 & $<$ LOQ & $<\mathrm{LOQ}$ \\
KTP & 0.2 & $<$ LOQ & 3.20 \\
NPX & 0.4 & $<$ LOQ & 0.60 \\
SMX & 0.2 & $<$ LOQ & 0.40 \\
\hline
\end{tabular}

Prototype effluent samples showed average values for turbidity removal $(28.58 \% \pm 5.15 \%)$ and transmittance increase $(20.66 \% \pm 2.30 \%)$ similar to those obtained in previously reported values for the GAC module (Table 4), so, the variation in these parameters is directly related to the GAC efficiency. On the other hand, an average removal of $43.36 \% \pm 12.14 \%$ of DOC was found in the prototype effluent. This is partly due to the efficiency of organic matter disposal in the GAC step (approximately $27.2 \% \pm 4.0 \%$ ), and the rest is due to its retention in the first stage (disc filters).

In all cases, the values obtained in prototype effluents for turbidity, TSS and $\mathrm{BOD}_{5}$ were lower than the most restrictive values reported in the recently published (EU) 2020/741 Regulation on minimum requirements for water reuse (turbidity $\leq 5 \mathrm{NTU}$, $\mathrm{TS} \leq 10 \mathrm{mg} / \mathrm{L}$ and $\mathrm{BOD}_{5} \leq 5 \mathrm{mg} / \mathrm{L}$ ), while EC and SAR were lower than $3 \mathrm{dS} / \mathrm{m}$ and 6, respectively, which is in accord with Spanish regulations (Royal Decree 1620/2007, https://www.boe.es/buscar/doc.php?id=BOE-A-2007-21092) [49]. In addition, microbiological indicators showed the total removal of selected parameters (according to Table 5), 
while values below the analytical limits set (Table 6) for the selected CECs were found in all cases, indicating high-quality agronomic effluents, suitable for safe, agricultural reuse purposes.

After the good results obtained, and taking into account the low concentrations of CECs found in the prototype influent and its stability, as shown in Table 1, an additional study using WWTP secondary effluents was carried out to evaluate the binomial high quality vs. volume of produced water, with a flow rate of $1200 \mathrm{~L} / \mathrm{h}$ (maximum prototype workflow). The results were similar to those obtained for a $500 \mathrm{~L} / \mathrm{h}$ workflow and showed high efficiency in terms of CECs removal with lower LOQ values in all cases, while the physico-chemical and microbiological indicators were below the standard limits indicated above. These results indicate that higher workflows could be used with medium-high quality water, while in water with a high concentration of CECs such as industrial wastewaters (which may also contain high values of turbidity or organic matter) it is necessary to work at low flows to ensure the high agronomic quality of the effluent. Thus, previous characterization of WWTP effluents is necessary.

Although high quality effluents were obtained in both minimum and maximum workflows ( 500 and $1200 \mathrm{~L} / \mathrm{h}$ ) in this particular case, after treatment of $715.33 \mathrm{~m}^{3}$ of wastewater, traces of CECs were found in prototype effluents ( $1200 \mathrm{~L} / \mathrm{h}$ workflow). In particular, between $0.5 \mu \mathrm{g} / \mathrm{L}$ to $1 \mu \mathrm{g} / \mathrm{L}$ of CBZ, DCF, KTP, and SMX were detected, suggesting the saturation of the GAC column.

For a more detailed study, the decrease in adsorption efficiency at different treated wastewater volumes was evaluated (Figure 7). In accord with the lower CECs concentration in real WWPT effluents, a few control experiments were programmed using real WWTP effluents containing selected CECs $\left(200 \mu \mathrm{g} / \mathrm{L}\right.$ of each). Different volumes of treated wastewater $\left(330,440\right.$ and $\left.715 \mathrm{~m}^{3}\right)$ were evaluated until the detected CECs point described above. The 500 and $1200 \mathrm{~L} / \mathrm{h}$ workflows were compared (Figure 7).

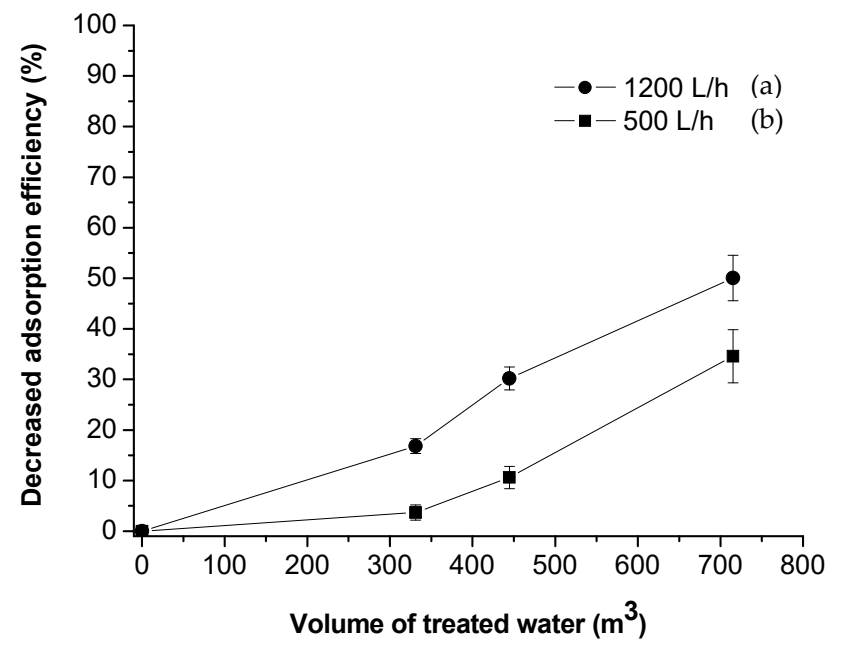

Figure 7. Decrease in adsorption efficiency at different treated wastewater volume in two workflows:

(a) $1200 \mathrm{~L} / \mathrm{h}$, (b) $500 \mathrm{~L} / \mathrm{h}$.

In both cases, the adsorption capacity decreased when the treated volume increased, suggesting that adsorption capacity gradually deteriorates with use. Specifically, a 50.05\% $\pm 4.48 \%$ and $34.58 \%$ $\pm 5.24 \%$ decrease in adsorption efficiency was obtained for 1200 and $500 \mathrm{~L} / \mathrm{h}$ workflows at $715 \mathrm{~m}^{3}$, respectively. The results suggest that when the adsorption capacity percentage decreases to around $50 \%$, the GAC should be replaced.

According to Chae et al. [50], the rate at which carbon is exhausted and the frequency at which carbon should be replaced/regenerated can be calculated by determining the carbon usage rate (CUR), which is the mass of activated carbon used per unit volume of wastewater treated (Equation (2)).

$$
\text { CUR }=\frac{\text { mass of GAC in column }}{\text { treated volume }}
$$


Therefore, according to this equation, and selecting $715.33 \mathrm{~m}^{3}$ as the maximum safety volume (conservative value for all possible prototype workflows), the CUR value obtained would be $0.15 \mathrm{~kg}$ of GAC per $\mathrm{m}^{3}$ of treated volume $\left(112 \mathrm{~kg} / 715.33 \mathrm{~m}^{3}\right)$, which can be used as a predictive value for scaled-up GAC systems.

\subsection{Applicability and Cost Assessment}

Although several technical or environmental factors have to be taken into account in the selection or feasibility of implementing an effective tertiary system, cost is often the determining factor. Taking into account the advantages of the selected GAC in the adsorption of CECs, we considered two possible scenarios.

The first scenario involves the implementation of the prototype in isolated areas, where an improvement in water quality is necessary prior to irrigating crops, in a conventional WWTP that does not have an installed tertiary treatment. An estimation of the operation and maintenance costs of the prototype (excluding installation) are shown in Table 7. Considering $8 \mathrm{~h}$ of work per day and 365 days/year ( $2920 \mathrm{~h} /$ year), the theoretical cost is $1300 € /$ year. On the other hand, if we consider the possibility of working at the maximum flow rate of the prototype $(1200 \mathrm{~L} / \mathrm{h})$, the expected treated volume of water is $3504 \mathrm{~m}^{3} /$ year. However, since the treated volume is approximately $90 \%$ of the total entry to the prototype (see Figure 3), the treated volume of water would be $3154 \mathrm{~m}^{3} /$ year. This means a maintenance cost of $0.37 € / \mathrm{m}^{3}$ treated or $0.41 € / \mathrm{m}^{3}$ produced, which is a relatively acceptable value given that the average cost of reused water treatment in Spain is about $0.46 € / \mathrm{m}^{3}$ for a system that includes a physico-chemical operation, membrane filtration, reverse osmosis and chlorination [51].

Table 7. Annual operation and maintenance cost of the prototype.

\begin{tabular}{lcc}
\hline Operation Type & Amount/Year & €/Year \\
\hline Maintenance $^{1}$ & $26 \mathrm{~h}$ & 390 \\
Cleaning $^{1}$ & $8 \mathrm{~h}$ & 120 \\
Operation $^{1}$ & $16 \mathrm{~h}$ & 240 \\
GAC change & 1 change & 350 \\
UV lamp & 0.25 ud & 200 \\
Electrical energy & Solar panels & 0 \\
\hline TOTAL & & 1300 \\
\hline
\end{tabular}

${ }^{1}$ Estimated cost of personnel: $15 € / \mathrm{h}$.

The second scenario is the inclusion of GAC modules in a conventional WWTP that already contain filtration steps and disinfection tertiary treatments. Thus, the long-term operational data from a WWTP with a conventional design was compared with the same design including a GAC step.

In the particular case of the Murcia region, the largest urban waste water regeneration system for the production of quality regenerated water 2.1 (according to the criteria of the Royal Decree 1620/2007 (2007), and MAPAMA recommendations (2010)) includes several stages: (1) coagulation-flocculation suspended matter reduction, using polyaluminium chloride (PAC) and anionic polyelectrolyte (PA); (2) filtration by sand filters, micro-sieves or textile filters; and (3) disinfection with UV lamps, and a final dose of $\mathrm{NaClO}$.

Assuming a duration of 20 years, and that inversion costs are evenly distributed over that time, the implementation of a GAC system in a conventional WWTP would increase costs from approximately $0.117 € / \mathrm{m}^{3}$ to $0.142 € / \mathrm{m}^{3}$, that is, an increase of $21 \%$. This increase is mainly due to the costs of replacing the GAC and the increased energy consumption of installations (around 25\%), while the remaining increase in costs is due to the initial investment $(12 \%)$ and $5 \%$ is due to equipment and facilities maintenance.

In both scenarios, the higher costs are related to the current limited capacity to regenerate GAC (replacement costs). However, regeneration studies, together with the development of new adsorbents 
capable not only of purifying water but also recovering valuable substances, provide useful perspectives on the implementation of these processes.

\section{Conclusions}

This work clearly demonstrates the feasibility of implementing a self-sufficient prototype in conventional WWTP as a tertiary treatment of effluent for agricultural reuse purposes. Regardless of the workflow, the use of GAC provides a promising way to reduce CECs concentration, while the UV lamp was able to remove all microbiological parameters analyzed (E. coli, total coliphages (F-specific and somatic) and Clostridium perfringens spores).

Lower workflows (high EBCT) increased the CECs removal efficiency, particularly for low molecular weight and aromatic compounds. However, to select the workflow, it is necessary to know the initial quality of the water to be treated (concentration and nature of CECs, presence of interferences, etc.), as well as the required quality of the produced water.

The use of the previous filtration stage (disc filters) obtained a good proportion of filtered water versus water consumption, while the energy autonomy and self-operation of the prototype resulted in an economically viable methodology for its implementation in conventional WWTPs, and in isolated areas linked to crops.

In view of the limited information available on the large-scale use of efficient tertiary treatments for reuse purposes, the information obtained in this study will help to provide a reference for efficient industrial designs.

Supplementary Materials: The following are available online at http://www.mdpi.com/2073-4441/12/8/2240/s1, Table S1: Activated carbon CG 900 characterization, Table S2: Solar panels characterization.

Author Contributions: Investigation, L.P.-R., B.M.-H., A.P.-M., A.J.G.-G.; writing-original draft preparation, L.P.-R.; writing-review and editing, L.P.-R., B.M.-H., A.P.-M., F.P.-S.; supervision, P.A.N.-T., J.J.A.-C., A.J.L.-G. and T.M.-P. All authors have read and agreed to the published version of the manuscript.

Funding: This research was supported by the strategic project Ris3mur REUSAGUA, funded by Consejería de Empleo, Universidades, Empresa y Medio Ambiente (Government of Murcia) under the European Regional Development Fund ERDF 2014-2020, which started in September 2016 and will run until the end of December 2020.

Acknowledgments: We would like to thank all the partners involved in the current project: Centro De Edafología y Biología Aplicada Del Segura (CEBAS), AZUD, Empresa Municipal de Aguas y Saneamiento de Murcia (EMUASA), Hidrogea, Instituto Murciano de Investigación y Desarrollo Agrario y Alimentario (IMIDA), Centro Tecnológico de la Energía y Medio Ambiente (CETENMA), Entidad de Saneamiento y Depuración de Aguas Residuales de la Región de Murcia (ESAMUR), Universidad de Murcia (UMU) and Universidad Politécnica de Cartagena (UPCT).

Conflicts of Interest: The funders had no role in the design of the study; in the collection, analyses, or interpretation of data; in the writing of the manuscript, or in the decision to publish the results.

\section{Appendix A}

pH and EC were measured with a multi-parameter equipment Eutech PC 2700 (Eutech instruments, Singapore). Turbidity was analyzed with a turbidity-meter Dinko D-110 (Dinko Instruments S.A., Barcelona, Spain). TSS values were determined according to American Standard Methods (American Public Health Association American Water Works Association, Water Pollution Control Federation, and Water Environmental Federation, 1915). Dissolved organic carbon (DOC) was measured in a Shimadzu 5050 TC-TOC-TN analyzer (Shimadzu Corporation S.L. Japan). Total Dissolved Nitrogen (TN) was measured using the same TC-TOC-TN analyzer. Ions were measured by ion chromatography using a Metrohm chromatograph (Metrohm, Switzerland). Samples for DOC, TN, spectrometry and chromatography methods were previously filtered using $45 \mu \mathrm{m}$ filters. 
Sodium Adsorption Ratio (SAR) was calculated based on the relation between soluble sodium and soluble calcium and magnesium divalent cations [52]:

$$
\mathrm{SAR}=\frac{\mathrm{Na}^{+}}{\sqrt{\left(\mathrm{Ca}^{+2}+\mathrm{Mg}^{+2}\right) / 2}}
$$

\section{References}

1. World Health Organization. WHO Guidelines for the Safe Use of Wasterwater Excreta and Greywater; World Health Organization: Geneva, Switzerland, 2006; Volume 1.

2. Voulvoulis, N. Water reuse from a circular economy perspective and potential risks from an unregulated approach. Curr. Opin. Environ. Sci. Health 2018, 2, 32-45. [CrossRef]

3. Official Website of the European Union. Available online: https://ec.europa.eu/environment/water/reuse.htm (accessed on 30 July 2020).

4. Lazarova, V.; Levine, B.; Sack, J.; Cirelli, G.; Jeffrey, P.; Muntau, H.; Salgot, M.; Brissaud, F. Role of water reuse for enhancing integrated water management in Europe and Mediterranean countries. Water Sci. Technol. 2001, 43, 25-33. [CrossRef]

5. Lazarova, V. Global milestones in water reuse: Keys to success and trends in development. Water 2013, 15, $12-22$.

6. Eslamian, S. Urban Water Reuse Handbook; CRC Press: Boca Raton, FL, USA, 2016.

7. Morari, F; Giardini, L. Municipal wastewater treatment with vertical flow constructed wetlands for irrigation reuse. Ecol. Eng. 2009, 35, 643-653. [CrossRef]

8. Meneses, M.; Pasqualino, J.C.; Castells, F. Environmental assessment of urban wastewater reuse: Treatment alternatives and applications. Chemosphere 2010, 81, 266-272. [CrossRef]

9. Pedrero, F.; Kalavrouziotis, I.; Alarcón, J.J.; Koukoulakis, P.; Asano, T. Use of treated municipal wastewater in irrigated agriculture-Review of some practices in Spain and Greece. Agric. Water Manag. 2010, 97, 1233-1241. [CrossRef]

10. Candela, L.; Fabregat, S.; Josa, A.; Suriol, J.; Vigués, N.; Mas, J. Assessment of soil and groundwater impacts by treated urban wastewater reuse. A case study: Application in a golf course (Girona, Spain). Sci. Total Environ. 2007, 374, 26-35. [CrossRef] [PubMed]

11. Alcon, F.; Pedrero, F.; Martin-Ortega, J.; Arcas, N.; Alarcon, J.J.; De Miguel, M.D. The non-market value of reclaimed wastewater for use in agriculture: A contingent valuation approach. Span. J. Agric. Res. 2010, 8, 187-196. [CrossRef]

12. Jhansi, S.C.; Mishra, S.K. Wastewater treatment and reuse: Sustainability options. Consilience 2013, 10, 1-15.

13. Official Website of the European Union. Available online: https://eur-lex.europa.eu/eli/reg/2020/741/oj (accessed on 28 June 2020).

14. European Parliament Website. Available online: https://www.europarl.europa.eu/thinktank/en/document. $\mathrm{html}$ ?reference=EPRS_BRI(2018)625171 (accessed on 30 July 2020).

15. Westerhoff, P.; Yoon, Y.; Snyder, S.; Wert, E. Fate of endocrine-disruptor, pharmaceutical, and personal care product chemicals during simulated drinking water treatment processes. Environ. Sci. Technol. 2005, 39, 6649-6663. [CrossRef] [PubMed]

16. Tran, N.H.; Reinhard, M.; Gin, K.Y.H. Occurrence and fate of emerging contaminants in municipal wastewater treatment plants from different geographical regions-A review. Water Res. 2018, 133, 182-207. [PubMed]

17. Li, B.; Zhang, T. Mass flows and removal of antibiotics in two municipal wastewater treatment plants. Chemosphere 2011, 83, 1284-1289. [CrossRef] [PubMed]

18. Rizzo, L.; Fiorentino, A.; Grassi, M.; Attanasio, D.; Guida, M. Advanced treatment of urban wastewater by sand filtration and graphene adsorption for wastewater reuse: Effect on a mixture of pharmaceuticals and toxicity. J. Environ. Chem. Eng. 2015, 3, 122-128. [CrossRef]

19. Krzeminski, P.; Tomei, M.C.; Karaolia, P.; Langenhoff, A.A.M.; Almeida, C.M.R.; Felis, E.; Gritten, F.; Andersen, H.R.; Fernandes, T.; Manaia, C.M.; et al. Performance of secondary wastewater treatment methods for the removal of contaminants of emerging concern implicated in crop uptake and antibiotic resistance spread: A review. Sci. Total Environ. 2019, 648, 1052-1081. [CrossRef] [PubMed] 
20. Behera, S.K.; Kim, H.W.; Oh, J.E.; Park, H.S. Occurrence and removal of antibiotics, hormones and several other pharmaceuticals in wastewater treatment plants of the largest industrial city of Korea. Sci. Total Environ. 2011, 409, 4351-4360. [CrossRef]

21. Radjenovic, J.; Petrovic, M.; Barceló, D. Analysis of pharmaceuticals in wastewater and removal using a membrane bioreactor. Anal. Bioanal. 2007, 387, 1365-1377. [CrossRef]

22. Directive, E.U. Directive 2013/39/EU of the European Parliament and of the Council of 12 August 2013 amending Directives 2000/60/EC and 2008/105/EC as regards priority substances in the field of water policy. Off. J. Eur. Union 2013, 226, 1-17.

23. Barbosa, M.O.; Moreira, N.F.; Ribeiro, A.R.; Pereira, M.F.; Silva, A.M. Occurrence and removal of organic micropollutants: An overview of the watch list of EU Decision 2015/495. Water Res. 2016, 94, 257-279.

24. Jurado, A.; Walther, M.; Díaz-Cruz, S. Occurrence, fate and environmental risk assessment of the organic microcontaminants included in the Watch Lists set by EU Decisions 2015/495 and 2018/840 in the groundwater of Spain. Sci. Total Environ. 2019, 663, 285-296. [CrossRef]

25. Grandclement, C.; Seyssiecq, I.; Piram, A.; Wongwahchung, P.; Vanot, G.; Tiliacos, N.; Roche, N.; Doumenq, P. From the conventional biological wastewater treatment to hybrid processes, the evaluation of organic micropollutant removal: A review. Water Res. 2017, 111, 297-317.

26. Tiwari, B.; Sellamuthu, B.; Ouarda, Y.; Drogui, P.; Tyagi, R.D.; Buelna, G. Review on fate and mechanism of removal of pharmaceutical pollutants from wastewater using biological approach. Bioresour. Technol. 2017, 224, 1-12. [CrossRef] [PubMed]

27. Ahmed, M.B.; Zhou, J.L.; Ngo, H.H.; Guo, W.; Thomaidis, N.S.; Xu, J. Progress in the biological and chemical treatment technologies for emerging contaminant removal from wastewater: A critical review. J. Hazard. Mater. 2017, 323, 274-298. [CrossRef] [PubMed]

28. Rodriguez-Narvaez, O.M.; Peralta-Hernandez, J.M.; Goonetilleke, A.; Bandala, E.R. Treatment technologies for emerging contaminants in water: A review. Chem. Eng. J. 2017, 323, 361-380. [CrossRef]

29. Joss, A.; Siegrist, H.; Ternes, T.A. Are we about to upgrade wastewater treatment for removing organic micropollutants? Water Sci. Technol. 2008, 57, 251-255. [CrossRef]

30. Benstöm, F.; Stepkes, H.; Rolfs, T.; Montag, D.; Pinnekamp, J. Reduction of Micropollutants Using Granular Activated Carbon in an Existing Flocculation Filter on a Municipal Waste Water Treatment Plant in Düren, Germany. 8 th Micropol E Ecohazard 2013. Available online: https://www.researchgate. net/publication/318908086_Reduction_of_micropollutants_using_Granular_Activated_Carbon_in_an_ existing_flocculation_filter_on_a_municipal_waste_water_treatment_plant_in_Duren_Germany (accessed on 8 August 2020).

31. Snyder, S.A.; Adham, S.; Redding, A.M.; Cannon, F.S.; Decarolis, J.; Oppenheimer, J.; Wert, E.C.; Yoon, Y. Role of membranes and activated carbon in the removal of endocrine disruptors and pharmaceuticals. Desalination 2007, 202, 156-181. [CrossRef]

32. Rossner, A.; Snyder, S.A.; Knappe, D.R. Removal of emerging contaminants of concern by alternative adsorbents. Water Res. 2009, 43, 3787-3796. [CrossRef]

33. Torrellas, S.Á.; Lovera, R.G.; Escalona, N.; Sepúlveda, C.; Sotelo, J.L.; García, J. Chemical-activated carbons from peach stones for the adsorption of emerging contaminants in aqueous solutions. Chem. Eng. J. 2015, 279, 788-798. [CrossRef]

34. Benstoem, F.; Pinnekamp, J. Characteristic numbers of granular activated carbon for the elimination of micropollutants from effluents of municipal wastewater treatment plants. Water Sci. Technol. 2017, 76, 279-285. [CrossRef]

35. Ahmed, M.J.; Hameed, B.H. Removal of emerging pharmaceutical contaminants by adsorption in a fixed-bed column: A review. Ecotox. Environ. Safe 2018, 149, 257-266. [CrossRef]

36. Bazan-Wozniak, A.; Pietrzak, R. Adsorption of organic and inorganic pollutants on activated bio-carbons prepared by chemical activation of residues of supercritical extraction of raw plants. Chem. Eng. J. 2020, 393, 124785. [CrossRef]

37. Hubetska, T.; Kobylinska, N.; García, J.R. Efficient adsorption of pharmaceutical drugs from aqueous solution using a mesoporous activated carbon. Adsorption 2020, 26, 251-266. [CrossRef]

38. Ravina, I.; Paz, E.; Sofer, Z.; Marm, A.; Schischa, A.; Sagi, G.; Yechialy, Z.; Lev, Y. Control of clogging in drip irrigation with stored treated municipal sewage effluent. Agric. Water Manag. 1997, 33, 127-137. [CrossRef] 
39. Duran-Ros, M.; Puig-Bargués, J.; Arbat, G.; Barragán, J.; de Cartagena, F.R. Performance and backwashing efficiency of disc and screen filters in microirrigation systems. Biosyst. Eng. 2009, 103, 35-42. [CrossRef]

40. Rahman, N.; Khan, M.F. Nitrate removal using poly-o-toluidine zirconium (IV) ethylenediamine as adsorbent: Batch and fixed-bed column adsorption modelling. J. Water Process Eng. 2016, 9, 254-266. [CrossRef]

41. Kårelid, V.; Larsson, G.; Björlenius, B. Pilot-scale removal of pharmaceuticals in municipal wastewater: Comparison of granular and powdered activated carbon treatment at three wastewater treatment plants. $J$. Environ. Manag. 2017, 193, 491-502. [CrossRef] [PubMed]

42. De Ridder, D.J.; Villacorte, L.; Verliefde, A.R.; Verberk, J.Q.; Heijman, S.G.J.; Amy, G.L.; Van Dijk, J.C. Modeling equilibrium adsorption of organic micropollutants onto activated carbon. Water Res. 2010, 44, 3077-3086. [CrossRef]

43. Boreen, A.L.; Arnold, W.A.; McNeill, K. Photochemical fate of sulfa drugs in the aquatic environment: Sulfa drugs containing five-membered heterocyclic groups. Environ. Sci. Technol. 2004, 38, 3933-3940. [CrossRef]

44. Yang, X.; Flowers, R.C.; Weinberg, H.S.; Singer, P.C. Occurrence and removal of pharmaceuticals and personal care products (PPCPs) in an advanced wastewater reclamation plant. Water Res. 2011, 45, 5218-5228. [CrossRef]

45. Motwani, P.; Vyas, R.K.; Maheshwari, M.; Vyas, S. Removal of sulfamethoxazole from wastewater by adsorption and photolysis. Nat. Environ. Pollut. Technol. 2011, 10, 51-58.

46. Telgmann, U.; Borowska, E.; Felmeden, J.; Frechen, F.B. The locally resolved filtration process for removal of phosphorus and micropollutants with GAC. J. Water Process Eng. 2020, 35, 101236. [CrossRef]

47. Sotelo, J.L.; Ovejero, G.; Rodríguez, A.; Álvarez, S.; Galán, J.; García, J. Competitive adsorption studies of caffeine and diclofenac aqueous solutions by activated carbon. Chem. Eng. J. 2014, 240, 443-453. [CrossRef]

48. Ang, T.N.; Young, B.R.; Taylor, M.; Burrell, R.; Aroua, M.K.; Baroutian, S. Breakthrough analysis of continuous fixed-bed adsorption of sevoflurane using activated carbons. Chemosphere 2020, 239, 124839. [CrossRef] [PubMed]

49. Decree, S.R. 1620/2007, 7 December 2007. Spanish Regulations for Water Reuse. Real Decreto, 1620. Available online: https://www.boe.es/buscar/doc.php?id=BOE-A-2007-21092 (accessed on 28 June 2020).

50. Chae, S.H.; Kim, S.S.; Jeong, W.; Park, N.S. Evaluation of physical properties and adsorption capacity of regenerated granular activated carbons (GACs). Korean J. Chem. Eng. 2013, 30, 891-897. [CrossRef]

51. Government of Spain website. Ministry of Environment and Rural and Marine Environment. National Water Quality Plan: Environmental Sustainability Report. 2010. Available online: https://www.miteco.gob. es/images/es/isa_pnra_231210_tcm30-183615.pdf (accessed on 31 July 2020).

52. Jiménez, B.; Asano, T. (Eds.) Water Reuse: An International Survey of Current Practice, Issues and Needs; IWA: London, UK, 2008.

(C) 2020 by the authors. Licensee MDPI, Basel, Switzerland. This article is an open access article distributed under the terms and conditions of the Creative Commons Attribution (CC BY) license (http://creativecommons.org/licenses/by/4.0/). 